CASSOWARY volume 4 (2) Juni 2021: 234-242

ISSN : 2614-8900

E-ISSN : 2622-6545

Program Pascasarjana Universitas Papua, https://pasca.unipa.ac.id

\title{
Keragaman Jenis Tanaman Pada Dua Sistem Pertanian di Pegunungan Arfak Papua Barat
}

\section{Crop Diversity Of Two Farming Systems in Arfak Mountains, West Papua}

\author{
Purbokurniawan $^{1}$, Siti Hajar Kubangun ${ }^{2}$, Alce Ilona Noya ${ }^{1}$, Yanuarius Anouw ${ }^{3}$ \\ ${ }^{1}$ Program Studi Agronomi, Fakultas Pertanian, Universitas Papua \\ ${ }^{2}$ Program Studi Ilmu Tanah, Fakultas Pertanian, Universitas Papua \\ ${ }^{3}$ Perkumpulan Bentara Papua Manokwari \\ *Email: purbokurniawan1977@gmail.com
}

Disubmit: 4 November 2020, direvisi: 31 Maret 2021, diterima: 10 April 2021

Doi: https://doi.org/10.30862/casssowary.cs.v4.i2.103

\begin{abstract}
The geographical of Pegunungan Arfak Regency was at $1200-2300$ meters above sea level, has a mountainous topography, potential for the development of economic highlands crops. The aim this research was to see the diversity of cultivated plant by Arfak people at Arfak mountainous in their field and yard farming system. These studies were conducted at 2 Districts: 1) Anggi: Testega, Bamaha and Kostera Village; 2) Anggi Gida at Tuabiam Village of Pegunungan Arfak Regency. The data collected by survey technique. The results showed there were a diversity of cultivated plants at two different farming system by Arfak people. There were 30 cultivated plants in four villages; consisted of 9 types of carbohydrate plants, 6 types of vegetable plants, 5 types of fruit plants, 8 types of spice plants and 2 types of sweeteners and fresheners. There were 11 crop in fields and 29 crop in yard farming system, respectively.
\end{abstract}

Keywords: Highlands, Cultivated Crop, Field, Yard

\section{PENDAHULUAN}

Secara geografis wilayah Kabupaten Pegunungan Arfak terletak pada ketinggian antara 1200 - 2300 mdpl (BPS, 2017). Wilayah Pegunungan Arfak ini didiami oleh masyarakat asli yang terdiri atas 3 suku besar. Ketiga suku besar tersebut yaitu Hatam, Moule dan Soughb (Hastanti dan Yeny, 2009). Suku Hatam mendiami wilayah Pegu-nungan Arfak bagian utara (meliputi wilayah Oransbari dan Ransiki), Suku Moule mendiami wilayah bagian timur Pegunungan Arfak (wilayah Minyambow) dan Suku Soughb mendiami wilayah bagian selatan Pegunungan Arfak (wilayah Anggi) (Mulyadi, 2012). Selain ketiga suku tersebut, terdapat juga suku Meyakh yang mendiami wilayah lembah bagian barat Pegunungan Arfak. Wilayah tersebut dikenal dengan sebutan dataran Prafi. Orang Arfak yang berada di wilayah Kabupaten Pegunungan Arfak mendiami zona ekologi kaki gunung, lembah-lembah kecil dan pegunungan tinggi. (Mulyadi, 2007).

Pegunungan Arfak memiliki topografi pegunungan sangat potensial untuk pengembangan tanaman dataran tinggi yang bernilai ekonomis. Pengembangan budidaya tanaman dataran tinggi yang akan dikembangkan di wilayah Pegunu- 
ngan Arfak sebaiknya sejalan dengan konsep kearifan lokal Suku Besar Arfak. Konsep ini menggambarkan hubungan yang harmonis antara masyarakat Arfak dengan alam lingkungan Pegunungan Arfak. Hubungan tersebut terjaga sampai saat ini karena telah diwariskan dari generasi ke generasi. Kearifan lokalnya disebut Igya Ser Hanjob yang memiliki makna menjaga lingkungan alam secara bersama-sama untuk kepentingan bersama (Hujairin, et., al., 2017).

Laksono, et., al., (2001) menyatakan bahwa konsep Igya Ser merupakan suatu konsep pembagian wilayah kon-servasi dalam melindungi alam lingku-ngannya. Wilayah tersebut dibagi men-jadi empat bagian, yaitu Bahamti, Nimahamti, Susti dan Situmti. Wilayah Susti dan Situmti dijadikan sebagai tempat membudidayakan tanaman atau bercocok tanam, sedangkan wilayah Nimahamti sebagai cadangan yang dapat dimanfaatkan untuk bercocok tanam. Hal ini dilakukan jika wilayah tersebut terpaksa dijadikan kebun. Wilayah Nimahamti tidak diperuntukkan sebagai tempat bercocok tanam tetapi dijadikan tempat untuk memperoleh kulit kayu, rotan, akar pohon dan daun untuk keperluan sehari-hari (Hujairin, et., al., 2017).

Wilayah Susti diperuntukkan sebagai kawasan pengelolaan untuk bercocok tanam, terletak jauh dari rumah/ pemukiman dan dikenal dengan istilah kebun atau ladang. Wilayah Situmti dikenal sebagai bekas kebun betatas. Kawasan ini terletak dekat pemukiman yang dikenal dengan istilah pekarangan (Mulyadi, 2012).

Wilayah Susti dijadikan kawasan bercocok tanam dengan sistem pertanian perladangan, sedangkan wilayah $\mathrm{Si}$ tumsi sebagai kawasan bercocok tanam dengan sistem pertanian pekarangan. Di kedua kawasan tersebut telah ditanam berbagai tanaman budidaya oleh masya- rakat Arfak. Dengan demikian perlu dilakukan suatu penelitian untuk melihat keragaman jenis tanaman budidaya pada sistem perladangan dan pekarangan di wilayah Pegunungan Arfak

\section{METODE}

Penelitian dilakukan di Kampung Testega, Bamaha, dan Kostera (Distrik Anggi) dan Kampung Tuabiam (Distrik Anggi Gida) Kabupaten Pegunungan Arfak. Penelitian ini berlangsung pada bulan Februari 2018.

Pengambilan data dilakukan menggunakan teknik survey. Survey dilaksanakan menggunakan metode deskriptif dengan teknik observasi lapang dan wawancara dengan masyarakat setempat. Observasi lapang dilakukan untuk mendapatkan gambaran mengenai keadaan umum wilayah setempat dan pengamatan secara langsung terhadap tanaman budidaya di lahan pekarangan dan perladangan. Wawancara dilakukan untuk mendapatkan informasi mengenai jenis-jenis pangan lokal dan teknik budidayanya. Sepuluh responden diwawancarai di setiap kampung sehingga total terdapat 40 responden.

Data yang diperoleh disajikan dalam bentuk tabulasi. Tiap jenis tanaman yang diperoleh pada kedua sistem per-tanian ditampilkan dalam bentuk tabel dan gambar.

\section{HASIL DAN PEMBAHASAN}

Hasil penelitian menunjukkan bahwa terdapat keragaman jenis tanaman budidaya di Kampung Testega, Bamaha, Kostera (Distrik Anggi) dan Kampung Tuabiam (Distrik Anggi Gida). Keragaman tersebut terlihat dari jumlah tanaman yang dibudidayakan petani yaitu sebanyak 30 jenis tanaman (Tabel 1). Hasil ini lebih tinggi dari laporan ILO PCdP2 UNDP (2018) yang mengidentifikasi 21 jenis sayuran budidaya di Kabupaten Manokwari dengan luas 
panen 1.163 Ha, namun lebih rendah dibandingkan keragaman tanaman di Kampung Ambaidiru Distrik Kosiwo, Kabupaten Yapen Waropen (54 jenis) (Sembori dan Tanjung, 2009). Ketiga puluh tanaman pada penelitian ini terdiri atas 9 jenis tanaman sumber karbohidrat, 6 jenis tanaman sayuran, 5 jenis tanaman buah-buahan, 8 jenis tanaman rempah, serta 2 jenis tanaman pemanis dan penyegar. Hampir semua jenis tanaman tersebut ditemukan pada dua sistem pertanian yang diamati.

Sembilan jenis tanaman sumber karbohidrat, yaitu ubijalar (Ipomoea batatas (L.) Lamk.), keladi (Xanthosoma sagittifolium (L.) Schott), talas (Colocasia esculenta (L.) Schott), ubikayu (Manihot esculenta Crantz), jagung (Zea mays L.), pisang (Musa spp.), kentang (Solanum tuberosum L.), kacang merah (Vigna ungu-iculata (L.) Walp.) dan labu kuning (Cucurbita moschata Duchesne) (Gambar 1). Enam jenis tanaman sayuran yaitu buncis (Phaseolus vulgaris L.), wortel (Daucus carota L.), kol (Brassica oleracea L.), sawi/petsai (Brassica juncea L.), labu siam (Sechium edule (Jacq.) Swartz.) dan selada air (Nasturtium officinale R.Br.) (Gambar 2). Lima jenis tanaman buah-buahan yaitu markisa ungu (Passiflora edulis Sims.), markisa kuning (Passi-flora ligularis), terong belanda (Sola-num betaceum Cav.), strowberi (Fraga-ria xananassa Duch.) dan alpukat (Per-sea americana Mill.) (Gambar 3). Delapan jenis tanaman rempah yaitu daun bawang (Allium fistulosum L.), seledri (Apium graveolens L.), bawang merah (Allium cepa L.), bawang putih (Allium sativum L.), tomat (Solanum lycopersicum L.), cabai rawit (Capsicum frutescens L.), sereh (Cymbopogon citratus) dan jeruk asam (Citrus spp.) (Gambar 4). Dua jenis tanaman pemanis dan penyegar yaitu tebu (Sacharum offisinarum L.) dan kopi (Coffea spp.) (Gambar 5).

\section{Sistem Perladangan}

Sebelas jenis tanaman budidaya ditanam pada lahan perladangan di keempat lokasi penelitian.. Enam jenis dari jumlah tersebut terdapat di Kampung Testega, Bamaha, dan Kostera di Distrik Anggi, serta Kampung Tuabiam di Distrik Anggi Gida. Lima jenis tanaman lain hanya ditemukan di beberapa kampung.

Tabel 1 menunjukkan keenam jenis tanaman yang ditemukan di keempat kampung pada sistem pertanian perladangan terdiri atas 4 jenis tanaman sumber karbohidrat, 1 jenis tanaman sayuran dan 1 jenis tanaman buah-buahan. Em-pat jenis tanaman sumber kahrbohidrat yaitu ubijalar, jagung, kentang dan labu kuning. Satu jenis tanaman sayuran yaitu buncis, sedangkan satu tanaman buahbuahan adalah markisa ungu. Buah markisa ungu hanya ditemukan pada sistem pertanian perladangan.

Lima jenis tanaman yang hanya ditemukan pada beberapa kampung saja adalah keladi, talas, ubikayu, kacang merah dan sawi/petsai. Tiga jenis tanaman sumber karbohidrat yaitu keladi, talas dan ubikayu ditemukan pada sistem pertanian perladangan di Kampung Tuabiam. Satu tanaman sumber karbohidrat kacang merah ditemukan pada sistem pertanian perladangan di Kampung Bamaha, Kostera dan Tuabiam. Satu tanaman sayuran yaitu sawi/ petsai ditemukan pada sistem pertanian perladangan di Kampung Bamaha dan Kostera. 
Tabel 1. Jenis tanaman budidaya yang ditemukan pada sistem budidaya tanaman pekarangan $(\mathrm{Pe})$ dan perladangan (La).

\begin{tabular}{|c|c|c|c|c|c|c|c|c|}
\hline \multirow{3}{*}{ Komoditas } & \multicolumn{8}{|c|}{ Kampung } \\
\hline & \multicolumn{2}{|c|}{ Bamaha } & \multicolumn{2}{|c|}{ Kostera } & \multicolumn{2}{|c|}{ Testega } & \multicolumn{2}{|c|}{ Tuabiam } \\
\hline & $\mathrm{Pe}$ & $\mathrm{La}$ & $\mathrm{Pe}$ & $\mathrm{La}$ & $\mathrm{Pe}$ & $\mathrm{La}$ & $\mathrm{Pe}$ & $\mathrm{La}$ \\
\hline \multicolumn{9}{|c|}{ Tanaman sumber kharbohidrat } \\
\hline Ubijalar & $\sqrt{ }$ & $\sqrt{ }$ & $\sqrt{ }$ & $\sqrt{ }$ & $\sqrt{ }$ & $\sqrt{ }$ & $\sqrt{ }$ & $\sqrt{ }$ \\
\hline Keladi & $\sqrt{ }$ & - & $\sqrt{ }$ & - & $\sqrt{ }$ & - & $\sqrt{ }$ & $\sqrt{ }$ \\
\hline Talas & $\sqrt{ }$ & - & $\sqrt{ }$ & - & $\sqrt{ }$ & - & $\sqrt{ }$ & $\sqrt{ }$ \\
\hline Ubikayu & - & - & - & - & - & - & $\sqrt{ }$ & $\sqrt{ }$ \\
\hline Jagung & $\sqrt{ }$ & $\sqrt{ }$ & $\sqrt{ }$ & $\sqrt{ }$ & $\sqrt{ }$ & $\sqrt{ }$ & $\sqrt{ }$ & $\sqrt{ }$ \\
\hline Pisang & $\sqrt{ }$ & - & $\sqrt{ }$ & - & $\sqrt{ }$ & - & $\sqrt{ }$ & - \\
\hline Kentang & $\sqrt{ }$ & $\sqrt{ }$ & $\sqrt{ }$ & $\sqrt{ }$ & $\sqrt{ }$ & $\sqrt{ }$ & $\sqrt{ }$ & $\sqrt{ }$ \\
\hline Kacang Merah & $\sqrt{ }$ & $\sqrt{ }$ & - & $\sqrt{ }$ & - & - & - & $\sqrt{ }$ \\
\hline Labu Kuning & $\sqrt{ }$ & $\sqrt{ }$ & $\sqrt{ }$ & $\sqrt{ }$ & $\sqrt{ }$ & $\sqrt{ }$ & $\sqrt{ }$ & $\sqrt{ }$ \\
\hline \multicolumn{9}{|c|}{ Tanaman sayuran } \\
\hline Buncis & $\sqrt{ }$ & $\sqrt{ }$ & $\sqrt{ }$ & $\sqrt{ }$ & - & $\sqrt{ }$ & - & $\sqrt{ }$ \\
\hline Wortel & $\sqrt{ }$ & - & $\sqrt{ }$ & - & $\sqrt{ }$ & - & $\sqrt{ }$ & - \\
\hline Kol & $\sqrt{ }$ & - & $\sqrt{ }$ & - & $\sqrt{ }$ & - & $\sqrt{ }$ & - \\
\hline Sawi/Petsai & $\sqrt{ }$ & $\sqrt{ }$ & $\sqrt{ }$ & $\sqrt{ }$ & $\sqrt{ }$ & - & $\sqrt{ }$ & - \\
\hline Labu Siam & $\sqrt{ }$ & - & $\sqrt{ }$ & - & $\sqrt{ }$ & - & $\sqrt{ }$ & - \\
\hline Selada Air & - & - & - & - & $\sqrt{ }$ & - & - & - \\
\hline \multicolumn{9}{|c|}{ Tanaman buah-buahan } \\
\hline Markisa ungu & - & $\sqrt{ }$ & - & $\sqrt{ }$ & - & $\sqrt{ }$ & - & $\sqrt{ }$ \\
\hline Markisa kuning & $\sqrt{ }$ & - & $\sqrt{ }$ & - & $\sqrt{ }$ & - & $\sqrt{ }$ & - \\
\hline Terong Belanda & $\sqrt{ }$ & - & - & - & - & - & - & - \\
\hline Strowberi & $\sqrt{ }$ & - & - & - & - & - & - & - \\
\hline Alpukat & $\sqrt{ }$ & - & - & - & - & - & $\sqrt{ }$ & - \\
\hline \multicolumn{9}{|c|}{ Tanaman Rempah } \\
\hline Daun Bawang & $\sqrt{ }$ & - & $\sqrt{ }$ & - & $\sqrt{ }$ & - & $\sqrt{ }$ & - \\
\hline Seledri & $\sqrt{ }$ & - & $\sqrt{ }$ & - & $\sqrt{ }$ & - & $\sqrt{ }$ & - \\
\hline Bawang Merah & $\sqrt{ }$ & - & $\sqrt{ }$ & - & $\sqrt{ }$ & - & $\sqrt{ }$ & - \\
\hline Bawang Putih & $\sqrt{ }$ & - & $\sqrt{ }$ & - & $\sqrt{ }$ & - & $\sqrt{ }$ & - \\
\hline Tomat & - & - & - & - & - & - & $\sqrt{ }$ & - \\
\hline Cabai Rawit & - & - & - & - & - & - & $\sqrt{ }$ & - \\
\hline Sereh & $\sqrt{ }$ & - & $\sqrt{ }$ & - & - & - & - & - \\
\hline Jeruk Asam & $\sqrt{ }$ & - & $\sqrt{ }$ & - & $\sqrt{ }$ & - & $\sqrt{ }$ & - \\
\hline \multicolumn{9}{|c|}{ Tanaman Pemanis dan Penyegar } \\
\hline Tebu & $\sqrt{ }$ & - & $\sqrt{ }$ & - & $\sqrt{ }$ & - & $\sqrt{ }$ & - \\
\hline Kopi & $\sqrt{ }$ & - & $\sqrt{ }$ & - & - & - & - & - \\
\hline
\end{tabular}




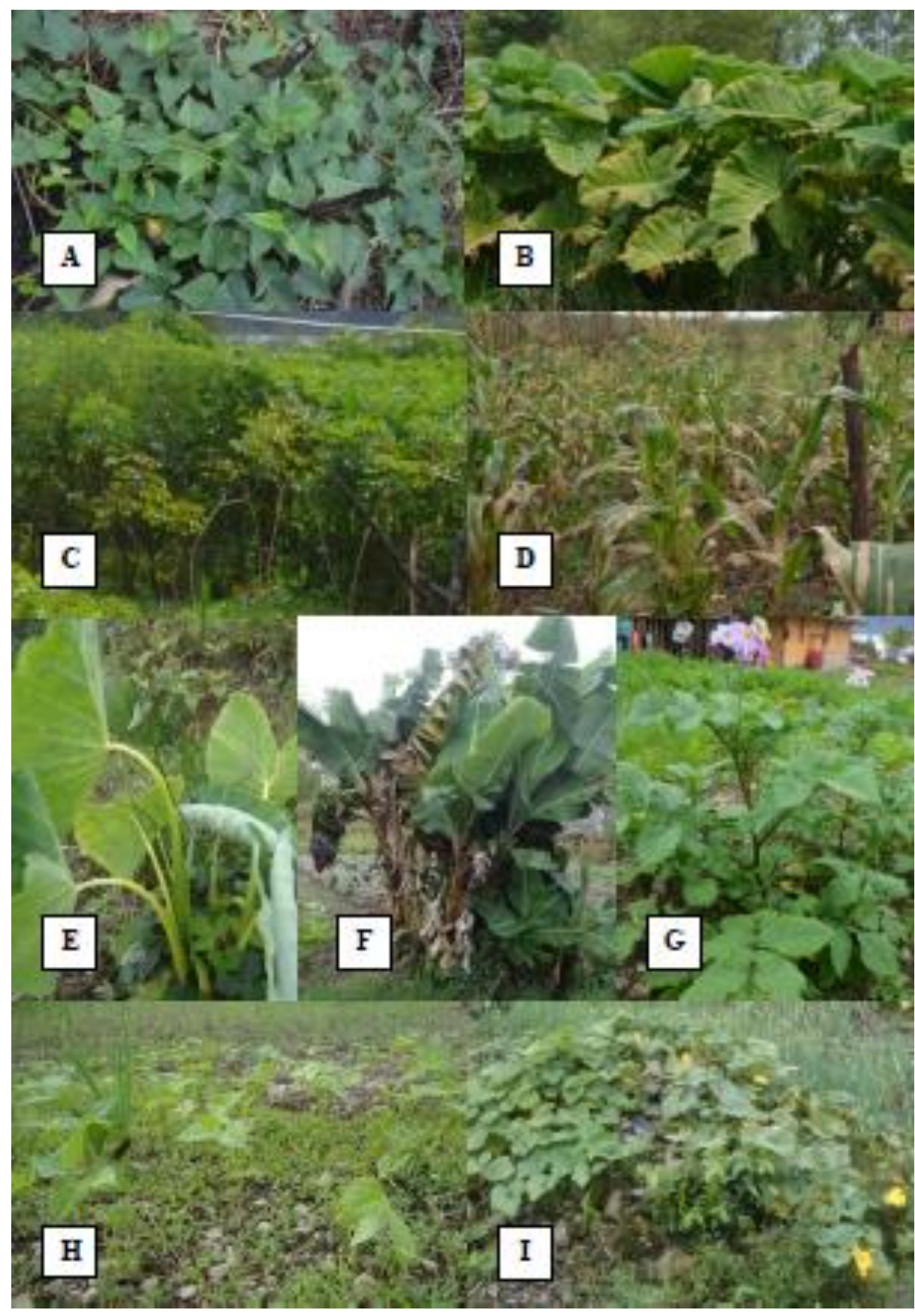

Gambar 1. Sembilan jenis tanaman sumber karbohidrat: ubijalar (A), keladi (B), ubikayu $(C)$, jagung $(\mathrm{D})$, talas $(\mathrm{E})$, pisang $(\mathrm{F})$, kentang $(\mathrm{G})$, kacang merah $(\mathrm{H})$ dan labu kuning (I). 


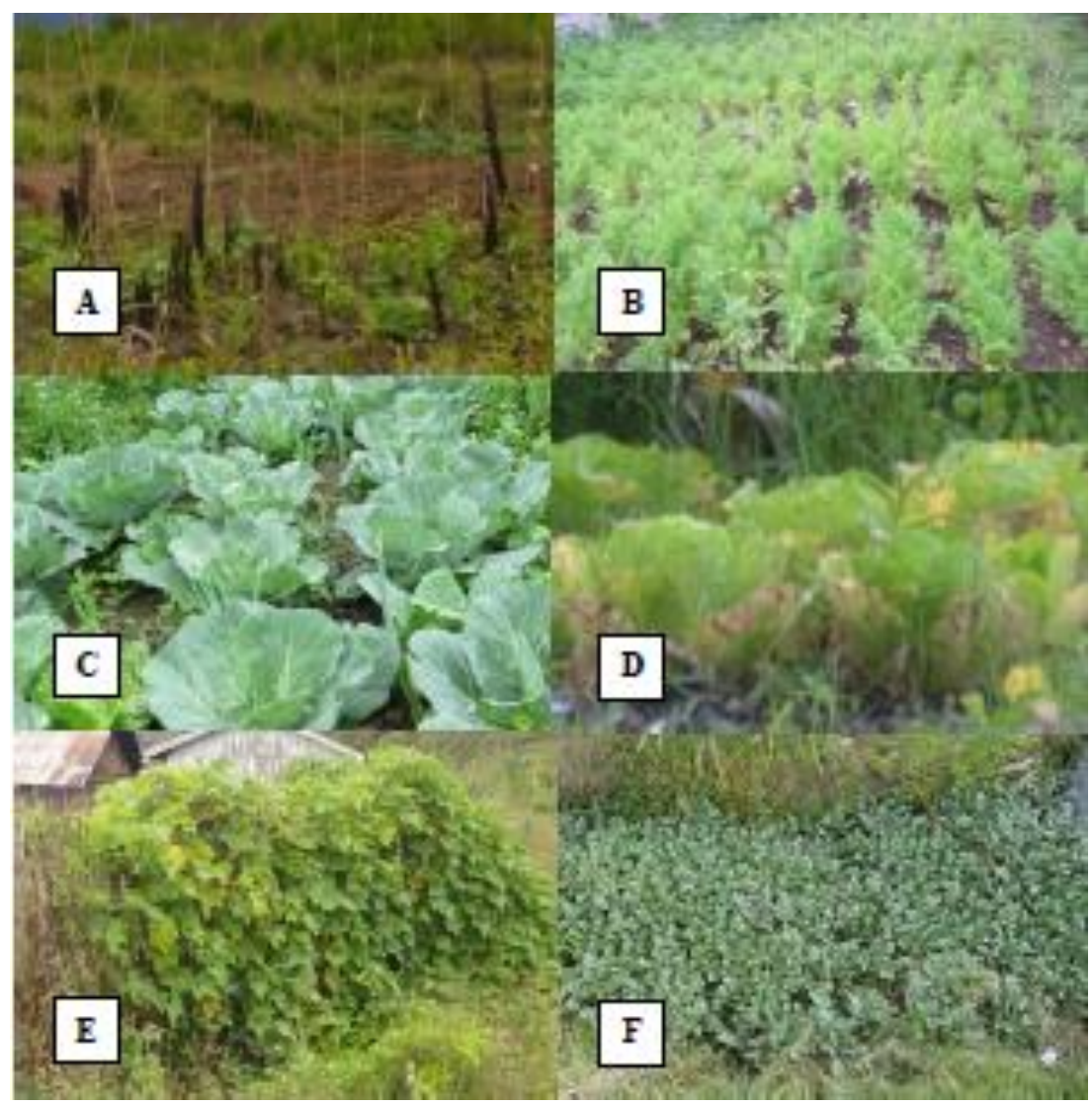

Gambar 2. Enam jenis tanaman sayuran: buncis (A), wortel (B), kol (C), sawi/petsai (D), labu siam (E) dan selada air (F).

\section{Sistem Pekarangan}

Dua puluh semibilan jenis tanaman budidaya ditemukan pada sistem pekarangan di Kampung Testega, Bamaha, dan Kostera, di Distrik Anggi serta Kampung Tuabiam di Distrik Anggi Gida. Hampir semua jenis tanaman $(96,67 \%)$ dari pengamatan pada penelitian ini ditemukan pada sistem pertanian pekarangan. Jumlah ini lebih sedikit jika dibandingkan dengan 45 jenis tanaman pangan di pekarangan masyarakat lokal di Distrik Heram, Jayapura (Lungga dan Simonapendi, 2017).

Satu jenis tanaman yang tidak ditemukan adalah buah markisa ungu (Ta- bel 1). Semua jenis tanaman yang dibudidayakan petani terdiri atas 9 jenis tanaman sumber karbohidrat, 6 jenis tanaman sayuran, 4 jenis tanaman buahbuahan, 8 jenis tanaman rempah serta 2 jenis tanaman pemanis dan penyegar. Apabila dibandingkan dengan laporan Lungga dan Simonapendi (2017) yang memperlihatkan terdapatnya 27 jenis tanaman buah di pekarangan Distrik Heram, hasil penelitian ini menunjukkan masyarakat di Kampung Testega, Bamaha dan Kostera di Distrik Anggi serta Kampung Tuabiam di Distrik Anggi Gida masih kurang memanfaatkan pekarangan untuk tanaman buahbuahan (hanya 4 jenis). 


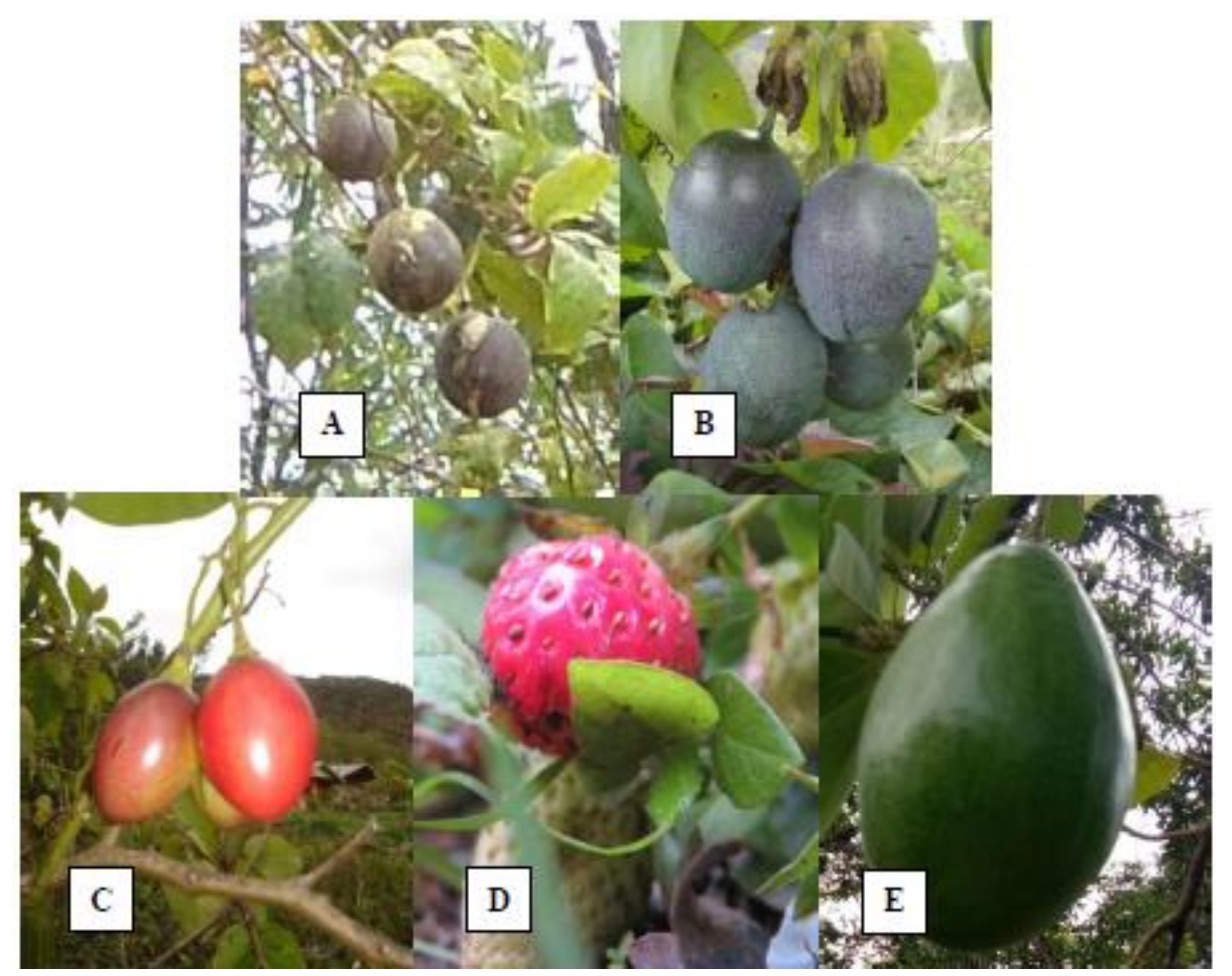

Gambar 3. Lima jenis tanaman buah-buahan: markisa ungu (A), markisa kuning (B), terong belanda (C), strowberi (D) dan alpukat (E).

Terdapat 18 jenis tanaman pada semua lahan pekarangan di Kampung Testega, Bamaha dan Kostera di Distrik Anggi, serta Kampung Tuabiam di Distrik Anggi Gida. Delapan belas tanaman tersebut terdiri atas 7 jenis tanaman sumber karbohidrat, 4 jenis tanaman sayuran, 1 jenis tanaman buah-buahan, 5 jenis tanaman rempah, serta 1 jenis tanaman pemanis dan penyegar.

Tujuh jenis tanaman sumber karbohidrat yaitu ubijalar, keladi, talas, jagung, pisang, kentang dan labu kuning (Gambar 1). Empat jenis tanaman sayuran yaitu wortel, kol, sawi/petsai dan labu siam (Gambar 2). Satu jenis tanaman buah-buahan yaitu markisa kuning (Gambar 3). Lima jenis tanaman rempah yaitu daun bawang, seledri, bawang merah, bawang putih dan jeruk asam (Gambar 4). Satu jenis tanaman pemanis dan penyegar yaitu tebu (Gambar 5).

Selain 18 jenis tanaman yang ditemukan di seluruh lahan sistem pekara- ngan pada keempat kampung tersebut, terdapat juga 11 jenis tanaman yang hanya terdapat di satu atau beberapa kampung saja yang membudidayakannya. Ubi kayu hanya ditemukan pada lahan pekarangan di Kampung Tuabiam, sedangkan kacang merah hanya ditemukan di Kampung Bamaha. Buncis ditemukan pada lahan sistem pekarangan Kampung Bamaha dan Kostera, sedangkan selada air hanya ditemukan di Kampung Testega. Tanaman buah terong belanda dan strowberi ditemukan di Kampung Bamaha. Pada pekarangan Kampung Bamaha dan Tuabiam ditemukan tanaman buah alpukat. Tanaman rempah tomat dan cabai rawit ditemukan pada lahan sistem pertanian pekarangan di kampung Tuabiam. Tanaman rempah sereh dan tanaman penyegar kopi ditemukan pada pekarangan di Kampung Bamaha dan Kostera. 


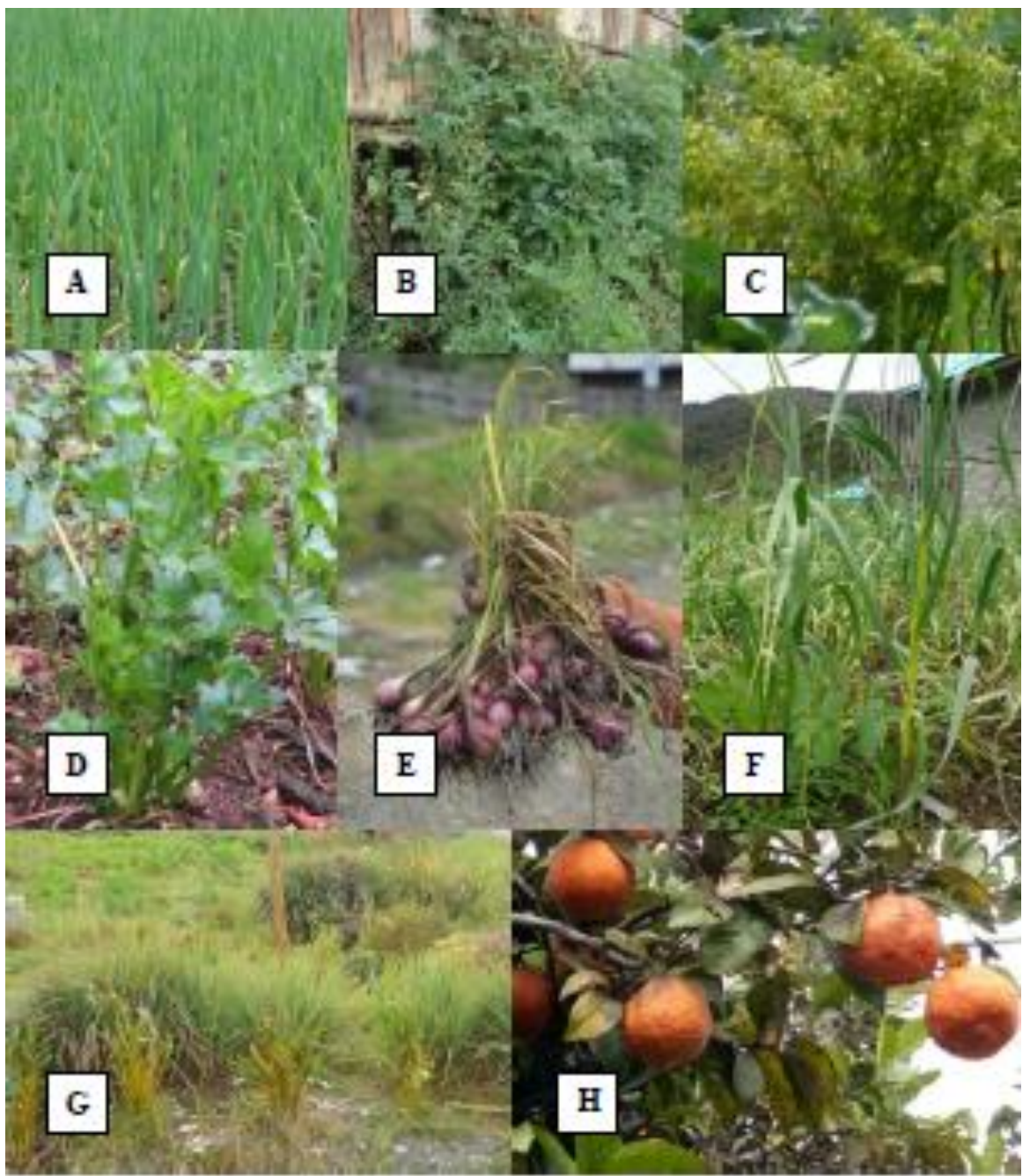

Gambar 4. Delapan jenis tanaman rempah: daun bawang (A), tomat (B), cabai rawit (C), seledri (D), bawang merah (E), bawang putih (F), sereh $(\mathrm{G})$ dan jeruk asam (H).

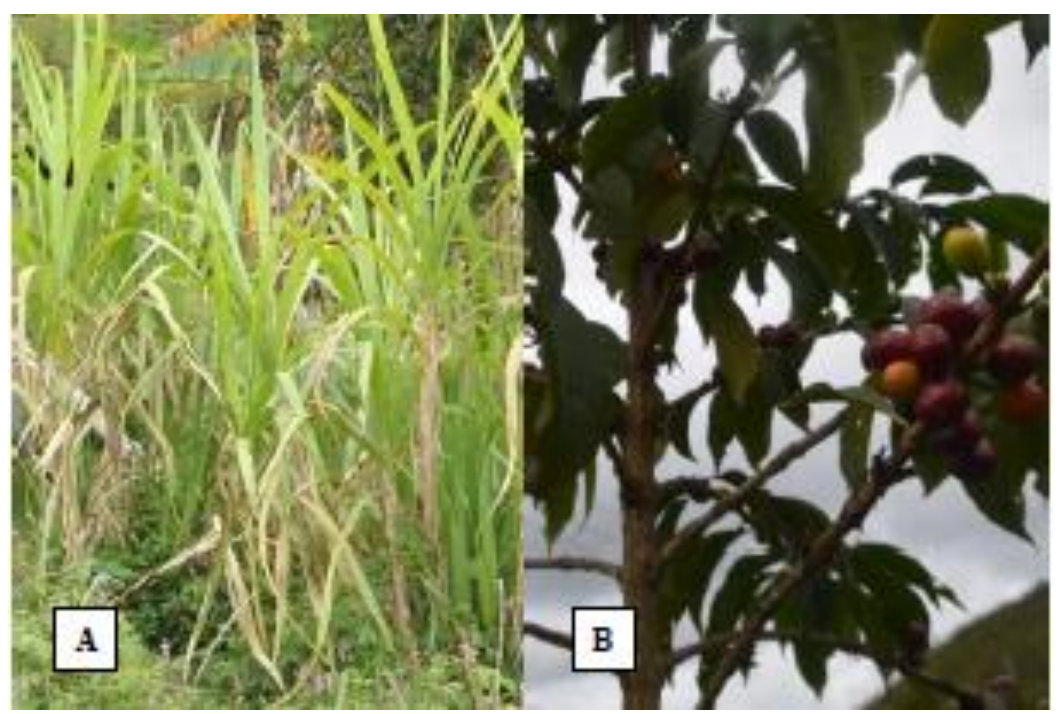

Gambar 5. Dua jenis tanaman pemanis dan penyegar: tebu (A) dan kopi (B). 


\section{SIMPULAN}

Terdapat keberagaman tanaman yang dibudidayakan oleh masyarakat Suku Arfak pada dua sistem pertanian yang berbeda. Tiga puluh jenis tanaman ditemukan pada kedua sistem pertanian yang terdiri atas 9 jenis tanaman sumber karbohidrat, 6 jenis tanaman sayuran, 5 jenis tanaman buah-buahan, 8 jenis tanaman rempah, serta 2 jenis tanaman pemanis dan penyegar. Sebanyak 11 jenis tanaman yang dibudidayakan pada sistem perladangan dan 29 jenis pada sistem pekarangan.

\section{UCAPAN TERIMA KASIH}

Ucapan terima kasih kepada The David and Lucille Packard Foundation yang telah mendukung penuh melalui dukungan dana sehingga penelitian ini dapat terlaksana dengan baik. Ucapan terima kasih juga disampaikan kepada Perkumpulan Bentara Papua yang senantiasa membantu dalam pelaksanaan penelitian di lapang.

\section{DAFTAR PUSTAKA}

Hastanti, B. W., I. Yeny. 2009. Strategi Pengelolaan Cagar Alam Pegunungan Arfak Menurut Kearifan Lokal Masyarakat Arfak di Manokwari Papua Barat. Info Sosial Ekonomi 9 (1) : 19-36

Hujairin, M., A. Ismadi, T. Kustana 2017. Revitalisasi Kearifan Lokal Suku Arfak di Papua Barat dalam Rangka Mendukung Ketahanan Pa- ngan Wilayah. Jurnal Prodi Manajemen Pertahanan 3 (1) : 53-77.

ILO-PCdP2 UNDP. 2018. Kajian Sayuran dengan Pendekatan Rantai Nilai dan Iklim Usaha di Kabupaten Manokwari. Laporan Studi Program Pembangunan berbasis Masyarakat Fase II: Implementasi Institusionalisasi Pembangunan Mata Pencaharian yang lestari untuk Masyarakat Papua.

Laksono, P. M., A. Riyanty, A.P. Hendrijani, Gunawan, A. Mandacan, N. Mansoara. 2001 Igya ser hanjop: masyarakat Arfak dan konsep konservasi. Pusat Studi Asia Pasifik, Universitas Gadjah Mada. Yogyakarta.

Lungga N., M. I. Simonapendi. 2017. Inventarisasi Tanaman Pangan pada Pekarangan Masyarakat Lokal Papua di Distrik Heram, Kota Jayapura. Jurnal Biologi Papua. 9(2): 43-48.

Mulyadi, 2007. Pengadopsian Inovasi Pertanian Suku Pedalaman Arfak (Kasus di Kabupaten Manokwari Papua Barat). [Disertasi]. Sekolah Pascasarjana Institut Pertanian Bogor.

Mulyadi. 2012. Budidaya Pertanian Papua: Perubahan Sosial dan Strategi Pemberdayaan Masyarakat Arfak. Karta Media. Yogyakarta.

Sembori F, R. H.R. Tanjung. 2009. Inventarisasi Jenis Tumbuhan Pangan Lokal pada Masyarakat Ambaidiru Kabupaten Yapen Waropen. Jurnal Biologi Papua. 1 (1): 36 - 41 